\title{
Place-Cell Impairment in Glutamate Receptor 2 Mutant Mice
}

\author{
Jun Yan, ${ }^{1}$ Yunfeng Zhang, ${ }^{1}$ Zhenping Jia,, ${ }^{2}$ Franco A. Taverna, ${ }^{3}$ Robert J. McDonald, ${ }^{4}$ Robert U. Muller, ${ }^{5}$ and \\ John C. Roder ${ }^{3}$ \\ ${ }^{1}$ Department of Physiology and Biophysics, University of Calgary, Calgary, T2N 4NI Canada, ${ }^{2 H}$ Hospital for Sick Children, \\ University of Toronto, Toronto, M5G 1 X8 Canada, ${ }^{3}$ Division of Development and Fetal Health, Mount Sinai Hospital \\ Research Institute, University of Toronto, Toronto, M5G 1X5 Canada, ${ }^{4}$ Department of Psychology, University of Toronto, \\ Toronto, M5G 1 X5 Canada, and 5Department of Physiology, State University of New York, New York, New York 12246
}

\begin{abstract}
There is a strong correlation between Hebbian, NMDA receptor-dependent long-term potentiation (LTP), place-cell firing, and learning and memory. We made glutamate receptor 2 (GluR2) null mutant mice that show enhanced non-Hebbian LTP in hippocampal CA1 neurons and impaired performance in a spatial learning task. We concluded that in vivo hippocampal place cells of GluR2 mutant mice were functionally impaired because (1) only $22.6 \%$ of CA1 neurons showed place fields in GluR2 mutant mice, which was significantly lower than that
\end{abstract}

The hippocampus has long been identified as a brain structure necessary to process certain kinds of learning and memory. It was initially revealed in humans that removal of the medial temporal lobe, including the hippocampus, resulted in a deficit in remembering newly acquired information (Scoville and Milner, 1957). A similar deficit has been reported in patients with more restricted lesions of the hippocampal CA1 area (Zola-Morgan et al., 1986). Behavioral studies indicate that animals with hippocampal lesions also show impaired performance in a variety of spatial learning tasks (O'Keefe et al., 1975; Olton et al., 1978; Morris et al., 1982; Sutherland et al., 1982, 1983). Therefore, it is thought that the hippocampus plays an evolutionarily conserved role in spatial learning and memory. The mechanisms underlying information storage in the hippocampus are not known, but parallel streams of research have revealed two possible candidates. One, long-term potentiation (LTP), has been thought to represent a synaptic form of encoding learned information (Bliss and Collingridge, 1993; Martin et al., 2000). The other lies at the level of neuronal firing by place cells that may constitute a cognitive map in the hippocampus (O'Keefe and Nadel, 1978).

Place cells are pyramidal neurons in the hippocampus that fire or increase their firing rate dramatically when the animal moves through a particular part of its environment (O'Keefe and Dostrovsky, 1971). In any given environment, each cell has its own field(s) of elevated firing, called a place field. However, firing rates are not predictable each time an animal moves through the

\footnotetext{
Received Aug. 6, 2001; revised Oct. 22, 2001; accepted Nov. 7, 2001.

This research was supported by the Canadian Institutes of Health Research and the Ontario Mental Health Foundation. We thank the Multiple Sclerosis Society of Canada for salary support, Kevin D. Willison for editing, and the Human Frontier Science Program Organization for a short-term training fellowship with Dr. R. Muller at the State University of New York (Brooklyn, NY).

Correspondence should be addressed to Dr. John Roder, Division of Development and Fetal Health, Mount Sinai Hospital Research Institute, University of Toronto, 600 University Avenue, Room 854, Toronto, Ontario, M5G 1X5 Canada. E-mail: roder@mshri.on.ca.

Copyright (ㄷ) 2002 Society for Neuroscience $\quad 0270-6474 / 02 / 220001-05 \$ 15.00 / 0$
}

(43.8\%) in wild-type mice; (2) GluR2 mutant place fields were much less precise; and (3) GluR2 mutant place fields were extremely unstable. Our data suggest that place cells of GluR2 knock-out mice did not form robust place fields, and that enhanced non-Hebbian LTP might play a negative role in their formation.

Key words: hippocampus; place cell; LTP; glutamate receptor; GluR2; knock-out mice place field (Fenton and Muller, 1998). Place fields are stable in the same environment between episodes (Barnes et al., 1997) and can last several months (Thompson and Best, 1990). However, remapping can occur if the environment is changed to a novel one.

Perturbations that affect Hebbian, NMDA receptor (NMDAR)-dependent LTP also affect place-cell firing and learning and memory (Martin et al., 2000). For example, the deletion of the NMDAR RI subunit only in the CA1 region of the hippocampus of adult mice caused a loss of LTP and profound impairments in hippocampal place-cell firing and mouse performance in the Morris water maze (McHugh et al., 1996; Tsien et al., 1996). In addition, mice that express an altered $\mathrm{Ca}^{2+}$ calmodulin-dependent kinase II also showed reduced LTP and long-term depression, lower learning and memory, and impaired place-cell activity (Rotenberg et al., 1996; Cho et al., 1998). Together these groups observed a decreased stability and firing rate of place cells and fewer correlations between the firing of cell pairs with overlapping place fields. The pharmacological blockade of NMDARs showed that the formation of place fields was normal, but that the long-term stability of place fields was impaired (Kentros et al., 1998). These data suggest that impaired place-cell activities are highly correlated with the reduced Heb-

This article is published in The Journal of Neuroscience, Rapid Communications Section, which publishes brief, peerreviewed papers online, not in print. Rapid Communications are posted online approximately one month earlier than they would appear if printed. They are listed in the Table of Contents of the next open issue of JNeurosci. Cite this article as: JNeurosci, 2002, 22:RC204 (1-5). The publication date is the date of posting online at www.jneurosci.org.

http://www.jneurosci.org/cgi/content/full/6032 
bian LTP as well as with hippocampal-dependent learning and memory.

The effect of non-Hebbian LTP on place-cell firing is not known. To test the relationship, we made a null mutation in the glutamate receptor 2 (GluR2) subunit of the AMPA receptor by gene targeting. These mice showed a predictable enhancement of non-NMDAR-dependant LTP (Jia et al., 1996). We show here for the first time that the spatial representation of place cells was impaired in GluR2 mutant mice. This implies that non-Hebbian LTP may inhibit normal place-cell formation and stability.

\section{MATERIALS AND METHODS}

Animal preparation, behavioral procedures, and data acquisition were similar to those described previously (Muller and Kubie, 1987; Muller et al., 1987; McHugh et al., 1996). Fourteen male laboratory mice weighing 23-34 gm were used in the present experiments. Six were wild types $(+/+)$ and eight were GluR2 null mutants $(-/-)$ of similar weight. All animals were housed in individual cages with access to food and water $a d$ libitum and were on a $12 \mathrm{hr}$ light/dark cycle starting from $3 \mathrm{~d}$ before the surgery and throughout the experiments. All animals were finally killed with $10 \%$ formalin perfusion under a large dosage of sodium pentobarbital; brain sections were made to histologically determine the recording site.

The recording electrodes used in the present experiments were 16wire electrodes. The core part of the electrodes consisted of four tetrodes, each of which was made from a twisted bundle of four $25 \mu \mathrm{m}$ Formvar-coated nichrome wires that were put into 26 gauge stainlesssteel tubing. Wires were cut off at the point $\sim 700 \mu \mathrm{m}$ apart from the end of the guiding tubing. The guiding tubing also served as the indifference electrode. Electrodes were mounted on a movable base.

To implant electrodes into the hippocampus, animals were anesthetized with sodium pentobarbital $(65 \mathrm{mg} / \mathrm{kg}$ body weight, i.p.) and atropine $(0.1 \mathrm{mg} / \mathrm{mouse}$, i.p.). When the eyelid closure reflex disappeared, the animal was mounted on a stereotaxic apparatus to immobilize the head. Petroleum jelly was applied to the eyes to prevent drying. Head hairs were removed, and the scalp was sterilized with $3 \%$ iodine and $70 \%$ ethanol. A longitudinal incision was made at the middle of the scalp. Temporal muscles were then dissected to expose the skull. Soft tissues on the exposed skull were removed, and all bleeding points were stopped. The skull was then processed with $1 \% \mathrm{H}_{2} \mathrm{O}_{2}$ and $100 \%$ ethanol. A hole that was $1 \mathrm{~mm}$ in diameter was made with a dental drill at the right skull above the hippocampus $(2.7 \mathrm{~mm}$ posterior to bregma and $2.7 \mathrm{~mm}$ lateral to the midline). After the dura matter was removed, a multiwire electrode was inserted into the brain to $\sim 700 \mu \mathrm{m}$ below the brain surface by putting the guiding tubing against the brain surface. Three legs of the movable base of the multiwire electrode were then fixed on the skull with dental cement so that the electrodes would firmly stand on the skull and could be moved up and down. The wound area was cleaned with saline and $70 \%$ ethanol and treated with both penicillin ointment and lidocaine ointment. The incision was closed with staples. For the first $2 \mathrm{~d}$ after surgery, the animal was given soft food and water in the cage. All animals were given 2 weeks to recover from surgery.

Behavioral training and experimental manipulation were performed in a custom-made, electromagnetically shielded, and acoustically reduced chamber $\left(1.5 \times 1.5 \times 2.0 \mathrm{~m}^{3}\right)$. A light disk (eight electric bulbs) was positioned at the center of the ceiling of the chamber and $2 \mathrm{~m}$ above the ground to provide shadeless illumination of the floor. The arena was seamless and was made of a gray plywood cylinder (49 $\mathrm{cm}$ diameter; 34 $\mathrm{cm}$ high). The cylinder was put at the center of the chamber and surrounded by a black curtain that was $1.5 \mathrm{~m}$ in diameter. White cardboard covered the cylinder wall by $90^{\circ}$ of the arc (one-fourth of the cylinder wall); this cardboard served as a visual cue inside the cylinder. The floor was a sheet of black paper that was changed after each training or recording session. A weight-balanced headstage with two lightemitting diode (LED) lights was suspended at the center of the cylinder through a 2-mm-thick cable. A video camera was mounted on the ceiling of the chamber and aimed at the center of the cylinder to track the animal's head position.

The electrophysiological recordings were made by connecting the suspended headstage to the electrodes implanted in the head of the animal. A headstage consisted of a field-effect transistor amplifier for each wire, two LED lights to label the animal's head position, and a cable used to transfer electrical signals to the recording system. Bioelectric signals from each wire were sent to a distribution panel, filtered with a bandpass of $0.3-10 \mathrm{kHz}$, and amplified 10 times with a differential amplifier separately. The position of the animal's head was tracked through a video camera by capturing LED signals, and these signals were fed to a television-based spot tracker. The LED signal was detected within a grid of $256 \times 256 \mathrm{U}$ regions (pixels). Off-line processing converted the resolution to $64 \times 64$, for which each pixel corresponded to $2.25 \mathrm{~cm}^{2}$. The sampling frequency was $40 \mathrm{kHz}$ for each recording channel (four channels) and $60 \mathrm{kHz}$ for the LED signal. Both signals were digitized via two analog-to-digital converting boards and collected with a Pentium II computer and Discovery software (DataWave Technologies, Minneapolis, MN). Each sampled signal was stamped with the time so that the recorded data for the action potential and position could be correlated with each other for data analysis.

At 2 weeks after surgery, 16 wires from four tetrodes were screened once daily for unit activities. If no complex spike cell was found, electrode bundles were lowered by $\sim 40 \mu \mathrm{m}$ and were screened the next day until one or more complex spike cells were found. To pick up CA1 neurons, the range of the search was restricted to within $1 \mathrm{~mm}$ deep from the implantation point. The recording sessions (16 min for each session) began once one or more complex spike activities were identified and the signal/noise ratio was $>2: 1$. The entire recording included three sessions. The first session was the control session. The second session was $30 \mathrm{~min}$ after the first session, and the cue card was rotated by $90^{\circ}$ counterclockwise. The third session started $30 \mathrm{~min}$ after the second session, with the cue card moved back to the same position as the first session. If place cells persisted $24 \mathrm{hr}$ after session 1, one additional recording session was recorded in the same environment as session 1.

Offline processing was first performed with Discovery software to isolate single units. Then the firing map of the complex spike cell was computed as the function of position using custom software. Firing rates in the entire area and in the field were computed with the spikes divided by time in the entire testing area or in the field area. Field size was expressed by percentage (pixels in the field divided by pixels in the entire testing arena). We also calculated coherence to evaluate the precision of place fields as well as angular displacement and the similarity (i.e., maximum cross-correlation) between two sessions to evaluate the stability of place fields (Rotenberg et al., 1996). Statistical $t$ tests and $\chi^{2}$ tests were used to compare the differences in data obtained from the two groups of mice.

\section{RESULTS}

Animals were allowed to explore the testing arena for $1 \mathrm{hr}$ each day over 3 consecutive days before electrode implantation. Therefore, the animal was considered to explore a familiar environment during recording sessions. To ensure sufficient data sampling, the mouse was allowed to run in the cylinder arena for 16 min so that it could cross most of the cylinder area (Muller and Kubie, 1987; Rotenberg et al., 1996). The data obtained from a recording session were excluded if the mouse crossed $<70 \%$ of the cylinder arena. The data were recorded only when the action potential showed complex spikes and if the signal/noise ratio was $>2$. The complex spike cells were identified on the oscilloscope according to physiological criteria described by Muller et al. (1987) [i.e., burst discharge, a silent period, and a long negative component of action potentials $(>0.3 \mathrm{msec})]$. In the present study, 48 complex spike cells were recorded in wild-type mice and 53 complex spike cells were recorded in GluR2 mutant mice. The overall average firing rate of complex spike cells over the 16 min recording session was $1.24 \pm 0.93 \mathrm{~Hz}$ for 48 wild-type cells and $1.47 \pm 2.02 \mathrm{~Hz}$ for 53 GluR2 mutant cells. These two firing rates were not statistically different $(p>0.05)$.

Of 48 cells from wild-type mice, 21 cells (43.75\%) showed location-specific firing, and one of them showed more than one place field. Of 53 cells from GluR2 mutant mice, only 12 (22.64\%) cells showed location-specific firing, and one of them had more than one place field. Therefore, hippocampal CA1 complex spike cells showed a much lower location-specific incidence in GluR2 mutant mice than in wild-type mice $(p<0.05)$. The average 


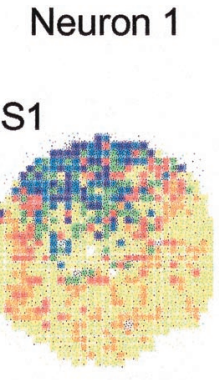

Neuron 2

Neuron 3
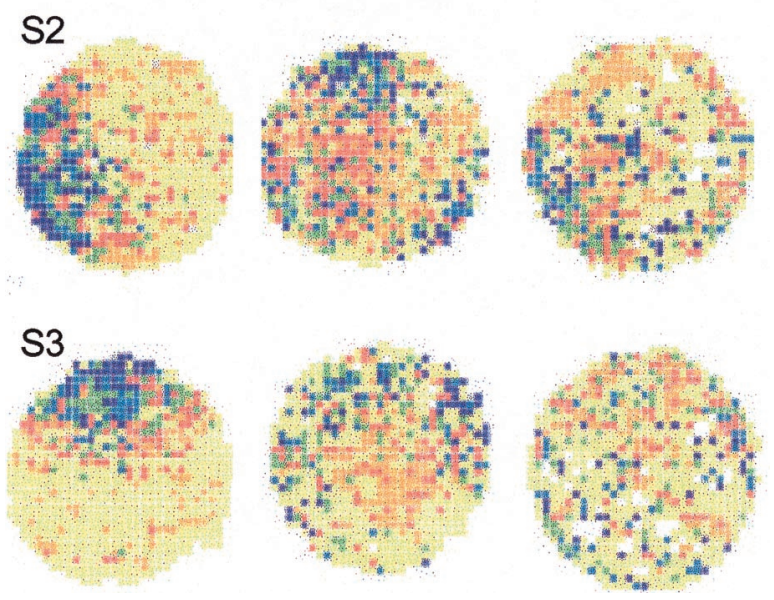

Figure 1. Examples of place cells of GluR2 wild-type and mutant mice. Neuron 1 was a place cell of a representative wild-type mouse that showed a clear-cut place field centered at 11:00 [session 1 (S1)]. When the white cue card was rotated $90^{\circ}$ counterclockwise, its place field moved to 8:00 [session $2(S 2)$ ]. Its field moved back to the original position when the cue card was moved back [session 3 (S3)]. Most of the GluR2 mutant place cells showed only fuzzy place fields, as shown by the appearances of Neuron 2 and Neuron $3(S 1)$. Their fields poorly followed the cue-card rotation ( $S 2$ and $S 3$ ). $S 1$ and $S 3$ refer to sessions 1 and 3, in which the cue card was at 12:00; $S 2$ refers to session 2 , in which the cue card was at 9:00.

firing rate in the place field was $4.86 \pm 1.02 \mathrm{~Hz}$ for wild-type cells and $5.33 \pm 0.61 \mathrm{~Hz}$ for GluR2 mutant cells, which were not significantly different $(p>0.05)$. Among those cells that showed location-specific firing, five wild-type cells and two GluR2 mutant cells showed place fields in the center of the cylinder; therefore, these cells were not used to calculate angular displacement and cross-correlation. Three additional mutant cells were not used because they lost the place field in session 2. The location, size, and shape of place fields of place cells were determined based on the function of the firing rate versus location over a $16 \mathrm{~min}$ recording period. For neurons that formed place fields, firing rate was not evenly distributed across the area of the testing arena; rather, the firing rate was distributed across a particular part of the arena, as shown in Figure 1. The field size showed large differences from cell to cell. The average sizes of place fields were $21.16 \pm 4.62 \%$ for wild-type cells and $24.55 \pm 6.23 \%$ for mutant cells. There was no statistical difference between them $(p>$ $0.05)$.

In addition to the low percentage of complex spike cells that showed location-specific firing, the place fields of GluR2 mutant cells (Fig. 1, neurons 2 and 3) were not clear-cut compared with wild-type cells (Fig. 1, neuron 1). In other words, the boundary of the place fields of GluR2 mutant cells was less clear than that of wild-type cells. The precision of the place field was evaluated by the coherence of firing rate of all adjacent pixels. A smooth and
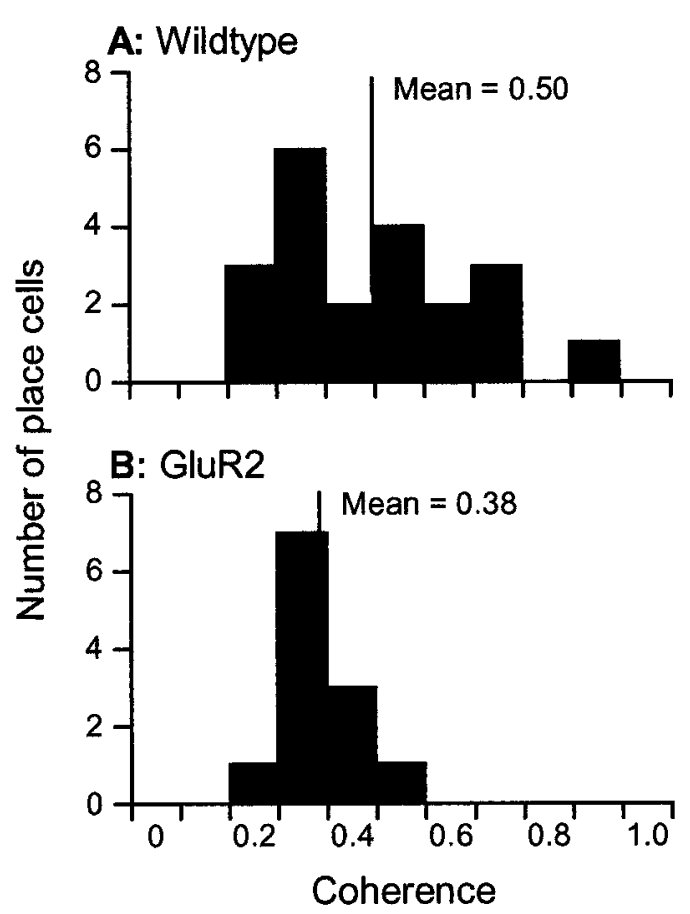

Figure 2. Distribution of the coherence of place cells of GluR2 wild-type and mutant mice. In wild-type mice, the distribution of coherence of place cells ranged up to 0.92 with a mean of $0.5(A)$. In the GluR2 mutant mice, however, most place cells had coherence around 0.3 with a mean of 0.38 $(B)$. The coherence of place fields in wild-type mice was significantly higher than that seen in GluR2 mutant mice $(p<0.05)$.

compact place field had high coherence; otherwise, coherence was low. An example of a wild-type place cell is shown in Figure 1 (left column); this cell had a clear-cut place field and a coherence value of 0.79 . Two examples of GluR2 mutant place cells shown in Figure 1 (neurons 2 and 3) had less condensed place fields; their coherence values were only 0.39 and 0.32 , respectively.

We calculated the coherence of all complex spike cells. The coherence ranged from -0.02 to 0.92 for wild-type cells and from -0.09 to 0.53 for GluR2 mutant cells. According to the criterion reported by Rotenberg et al. (1996), a coherence value of 0.26 was used to judge the place cells from nonplace cells. In the present study, all place cells judged by visual inspection showed coherence of $>0.26$; those cells with no place field had coherence values of $<0.26$. The average coherence for 21 wild-type place cells was $0.50 \pm 0.19$, and the coherence of 12 GluR2 mutant place cells was $0.38 \pm 0.08$. The coherence was significantly different between wild-type and GluR2 mutant place cells (Fig. 2) $(p<0.05)$.

The stability of place cells was assessed by comparison of the angular displacement and similarity between sessions in 16 wildtype cells and 7 GluR2 mutant cells. The ideal angular displacement of a place field was $0^{\circ}$ by reference to the actual position of a cue card that underwent a $90^{\circ}$ rotation in the second session and was moved back to $0^{\circ}$ in the third session. The actual angular displacement was the degree at which the maximum similarity was generated. The difference in angular displacement between ideal and actual values indicated the stability of place fields. When the cue card was rotated $90^{\circ}$, the angular displacement and similarity of wild-type place cells were $29.19 \pm 20.32$ and $0.37 \pm$ 0.11 , respectively. The angular displacement and similarity of 


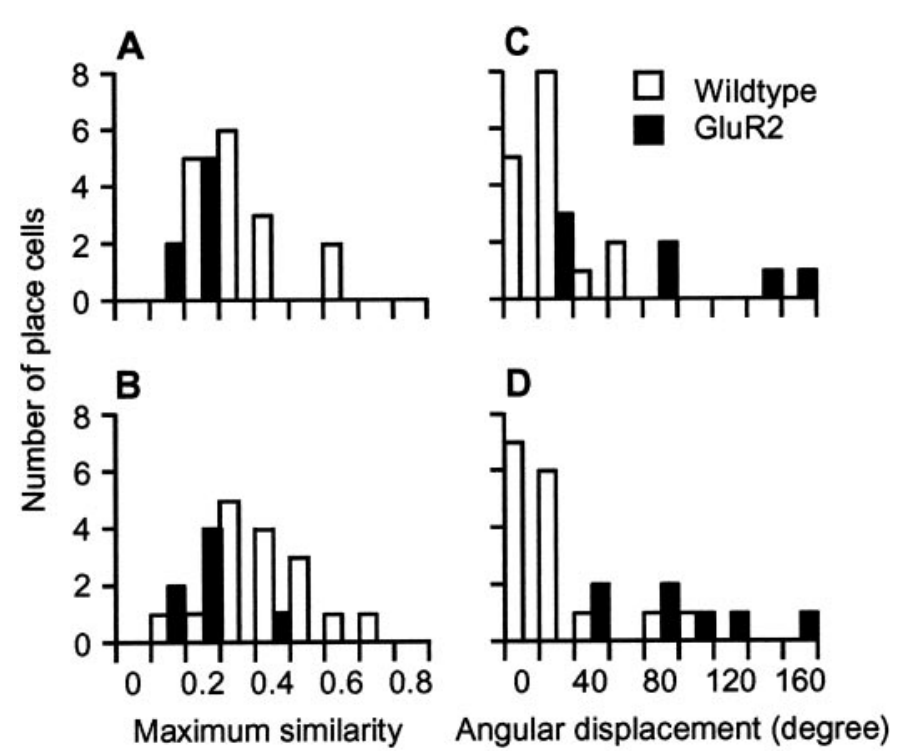

Figure 3. Distribution of the maximum similarity and angular displacement for GluR2 wild-type and mutant mice. By the reference to session 1, the similarities of GluR2 mutant place cells in sessions 2 and 3 were significantly lower than those of wild-type place cells $(A, B ; p<0.001$ for both sessions), whereas the angular displacements of GluR2 mutant mice were significantly higher than those of wild-type mice $(C, D ; p<0.05$ for session 2 and $p<0.01$ for session 3 ).

GluR2 mutant place cells were $86.14 \pm 57.31$ and $0.23 \pm 0.06$, respectively (Fig. $3 A, B$ ). Statistical analysis indicated that the angular displacement of wild-type mice was significantly smaller than that of GluR2 mutant mice $(p<0.05)$, whereas the similarity of the wild-type mice was significantly higher than that of GluR2 mutant mice $(p<0.001)$ for the $90^{\circ}$ cue-card rotation. When the cue card was rotated back to $0^{\circ}$, the angular displacement and similarity of wild-type and GluR2 mutant place cells were similar to those of a $90^{\circ}$ rotation $(29.13 \pm 31.11$ and $0.42 \pm$ 0.14 vs $98.43 \pm 44.57$ and $0.24 \pm 0.08$, respectively) (Fig. $3 C, D$ ). Angular displacement and similarity between wild-type and GluR2 mutant place cells were also significantly different $(p<$ 0.01 and $p<0.001$ ). In the session that took place on day 2, 11 of 16 wild-type cells and only 1 of 7 mutant cells reappeared. The average angular displacement and similarity with reference to session 1 were $28.93 \pm 25.12$ and $0.38 \pm 0.16$, respectively, for wild-type cells. Those for one mutant cell were 52.81 and 0.27 .

\section{DISCUSSION}

The present study demonstrates clear differences in CA1 place cells between GluR2 mutant and wild-type mice. GluR2 mutant mice show a significantly lower number of place cells as well as poorly defined and extremely unstable place fields. Our data suggest that the spatial representation of place cells is impaired in GluR2 mutants. This is consistent with what we have found in behavioral experiments, which show that GluR2 mutant mice have dysf unctional spatial learning abilities (Gerlai et al., 1998).

The basis for enhanced LTP in GluR2 mutants is well established. In the CNS of mammals, AMPA receptor subtypes of glutamate receptors consist of four subunits, GluR1, GluR2, GluR3, and GluR4. The relative level of these subunits underlies the $\mathrm{Ca}^{2+}$ permeability through the channel (Geiger et al., 1995). GluR2 is the key subunit for controlling the $\mathrm{Ca}^{2+}$ permeability. In principal neurons of the hippocampus, the GluR2 subunit is highly expressed so that they show low $\mathrm{Ca}^{2+}$ permeability (Bur- nashev et al., 1992). GluR2 mutant mice, in which GluR2 subunits were genetically deleted (Jia et al., 1996), showed high $\mathrm{Ca}^{2+}$ permeability in CA1 neurons and largely enhanced NMDAindependent, non-Hebbian LTP with normal presynaptic function (Jia et al., 1996; Mainen et al., 1998).

The enhanced non-Hebbian LTP could account for impaired place-cell activities and spatial learning deficits in GluR2 mice. Models of information storage in the hippocampus rely on Hebbian mechanisms of synaptic strengthening (Lisman, 1999). Networks of interconnected neurons showing Hebbian properties are capable of storing large numbers of memories in their recurrent synapses (Kohonen, 1978; Hopfield, 1982). Furthermore, because all synapses are strengthened in the GluR2 mutant hippocampus, the relative strengthening of each synapse is zero (i.e., saturated). If LTP is considered to be a type of information storage in the brain, nonspecific enhanced LTP cannot store information. Therefore, in GluR2 mice, poor spatial representation of hippocampal place cells might be a consequence of the enhanced but unspecific non-Hebbian LTP.

Another possible explanation could be that the deletion of the GluR2 gene might have caused a compensatory change in development and might abnormally trigger intracellular signaling cascades because of the increased calcium influx, which should affect place-cell activities. For example, this cascade in the extra $\mathrm{Ca}^{2+}$ influx could activate calcineurin, which we have shown directly alters the firing of CA1 neurons by its action or the $\mathrm{GABA}_{\mathrm{A}}$ receptor ( $\mathrm{Lu}$ et al., 2000). An increase in cell membrane input resistance suggests either reduced cell size or reduced dendritic arborization in GluR2 mutant mice (Jia et al., 1996). No other change in the development of the hippocampus or CNS at large was found in GluR2 mutant mice (Jia et al., 1996; Gerlai et al., 1998; Mainen et al., 1998). Therefore, we favor the hypothesis that place-cell function is impaired as a direct physiological consequence of the loss of GluR2.

It is necessary to note that the spatial representation of hippocampal place cells relies on the integration of various signals that are processed in many other brain structures before the hippocampus. Damage to those brain structures, such as the fornix and parahippocampal cortices, results in instability of hippocampal place fields (Miller and Best, 1980; Cooper and Mizumori, 2001; Muir and Bilkey, 2001). Because the GluR2 subunit is widely distributed in the brain (Martin et al., 1993; Sato et al., 1993), global deletion of the GluR2 subunit possibly changes functions of other areas too. Therefore, in addition to the enhanced non-Hebbian LTP in the hippocampus, potential deficits in cell functions of other brain regions might also contribute to poor spatial representation of hippocampal place cells in GluR2 mutants.

The strongly enhanced, non-Hebbian LTP found in the hippocampus of GluR2 mutant mice was associated with impaired place-cell function in the hippocampus. For example, the incidence of complex spike cells (pyramidal cells) that show locationspecific firing was much lower in GluR2 mutant mice. Even in those few GluR2 mutant cells $(22.64 \%)$ showing location-specific firing, their place fields were poorly defined and extremely unstable. Therefore, the function of hippocampal place cells in GluR2 mutant mice is impaired. This is consistent with the deficit of learning and memory we have found in GluR2 mutant mice.

\section{REFERENCES}

Barnes CA, Suster MS, Shen J, McNaughton BL (1997) Multistability of cognitive maps in the hippocampus of old rats. Nature 388:272-275. 
Bliss TVP, Collingridge GL (1993) A synaptic model of memory: longterm potentiation in the hippocampus. Nature 361:31-39.

Burnashev N, Monyer H, Seeburg PH, Sakmann B (1992) Divalent ion permeability of AMPA receptor channels is dominated by the edited form of a single subunit. Neuron 8:189-198.

Cho YH, Giese KP, Tanila H, Silva AJ, Eichenbaum H (1998) Abnormal hippocampal spatial representations in $\alpha$ CaMKIIT286A and CREB $\alpha \Delta-$ mice. Science 279:867-869.

Cooper BG, Mizumori SJ (2001) Temporary inactivation of the retrosplenial cortex causes a transient reorganization of spatial coding in the hippocampus. J Neurosci 21:3986-4001.

Fenton AA, Muller RU (1998) Place cell discharge is extremely variable during individual passes of the rat through the firing field. Proc Natl Acad Sci USA 95:3182-3187.

Geiger JR, Melcher T, Koh DS, Sakmann B, Seeburg PH, Jonas P, Monyer H (1995) Relative abundance of subunit mRNAs determines gating and $\mathrm{Ca}^{2+}$ permeability of AMPA receptors in principal neurons and interneurons in rat CNS. Neuron 15:193-204.

Gerlai R, Henderson JT, Roder JC, Jia Z (1998) Multiple behavioral anomalies in GluR2 mutant mice exhibiting enhanced LTP. Behav Brain Res 95:37-45.

Hopfield JJ (1982) Neural networks and physical systems with emergent collective computational abilities. Proc Natl Acad Sci USA 79:2554-2558.

Jia Z, Agopyan N, Miu P, Xiong Z, Henderson J, Gerlai R, Taverna FA, Velumian A, MacDonald J, Carlen P, Abramow-Newerly W, Roder J (1996) Enhanced LTP in mice deficient in the AMPA receptor GluR2. Neuron 17:945-956.

Kentros C, Hargreaves E, Hawkins RD, Kandel ER, Shapiro M, Muller RV (1998) Abolition of long-term stability of new hippocampal place cell maps by NMDA receptor blockade. Science 280:2121-2126.

Kohonen T (1978) Associative memory. Berlin: Springer.

Lisman JE (1999) Relating hippocampal circuitry to function: recall of memory sequences by reciprocal dentate-CA3 interactions. Neuron 22:233-242.

Lu YM, Mansuy IM, Kandel ER, Roder J (2000) Calcineurin-mediated LTD of GABAergic inhibition underlies the increased excitability of CA1 neurons associated with LTP. Neuron 26:197-205.

Mainen ZF, Jia Z, Roder J, Malinow R (1998) Use-dependent AMPA receptor block in mice lacking GluR2 suggests postsynaptic site for LTP expression. Nat Neurosci 1:579-586.

Martin SJ, Blackstone CD, Levey AI, Huganir RL, Price DL (1993) AMPA glutamate receptor subunits are differentially distributed in rat brain. Neuroscience 53:327-358.

Martin SJ, Grimwood PD, Morris RGM (2000) Synaptic plasticity and memory: an evaluation of the hypothesis. Annu Rev Neurosci 23:649-711.

McHugh TJ, Blum KI, Tsien JZ, Tonegawa S, Wilson MA (1996) Impaired hippocampal representation of space in CA1-specific NMDAR1 knockout mice. Cell 87:1339-1349.
Miller VM, Best PJ (1980) Spatial correlates of hippocampal unit activity are altered by lesions of the fornix and entorhinal cortex. Brain Res 194:311-323.

Morris RGM, Garrud P, Rowlins JNP (1982) Place navigation impaired in rats with hippocampal lesions. Nature 297:681-683.

Muir GM, Bilkey DK (2001) Instability in the place field location of hippocampal place cells after lesions centered on the perirhinal cortex. J Neurosci 21:4016-4025.

Muller RU, Kubie JL (1987) The effects of changes in the environment on the spatial firing of hippocampal complex-spike cells. J Neurosci 7:1951-1968.

Muller RU, Kubie JL, Ranck Jr JB (1987) Spatial firing patterns of hippocampal complex-spike cells in a fixed environment. J Neurosci 7:1935-1950.

O'Keefe J, Dostrovsky J (1971) The hippocampus as a spatial map: preliminary evidence from unit activity in the freely-moving rat. Brain Res 34:171-175.

O'Keefe J, Nadel L (1978) The hippocampus as a cognitive map. Oxford, UK: Clarendon.

O'Keefe J, Nadel L, Keightly S, Kill D (1975) Fornix lesions selectively abolish place learning in the rat. Exp Neurol 48:152-166.

Olton DS, Walker JA, Gage FH (1978) Hippocampal connections and spatial discrimination. Brain Res 139:295-308.

Rotenberg A, Mayford M, Hawkins RD, Kandel ER, Muller RU (1996) Mice expressing activated CaMKII lack low frequency LTP and do not form stable place cells in the CA1 region of the hippocampus. Cell 87:1351-1361.

Sato K, Kiyama H, Tohyama M (1993) The differential expression patterns of messenger RNAs encoding non- $N$-methyl-D-aspartate glutamate receptor subunits (GluR1-4) in the rat brain. Neuroscience 52:515-539.

Scoville WB, Milner B (1957) Loss of recent memory after bilateral hippocampal lesions. J Neurol Neurosurg Psychiatry 20:11-12.

Sutherland RJ, Kolb B, Whishaw IQ (1982) Spatial mapping: definitive disruption by hippocampal or medial frontal cortical damage in the rat. Neurosci Lett 31:271-276.

Sutherland RJ, Whishaw IQ, Kolb B (1983) A behavioural analysis of spatial localization following electrolytic, kainite- or colchicine-induced damage to the hippocampal formation in the rat. Behav Brain Res 7:133-153.

Thompson LT, Best PJ (1990) Long-term stability of the place-field activity of single units recorded from the dorsal hippocampus of freely behaving rats. Brain Res 509:299-308.

Tsien JZ, Huerta PT, Tonegawa S (1996) The essential role of hippocampal CA1 NMDA receptor-dependent synaptic plasticity in spatial memory. Cell 87:1327-1338.

Zola-Morgan S, Squire LR, Amaral D (1986) Human amnesia and the medial temporal region: enduring memory impairment following a bilateral lesion limited to field CA1 of the hippocampus. J Neurosci 6:2950-2967. 